\title{
Vale Professor Michael Gaffikin
}

Parulian Silaen ${ }^{1}$

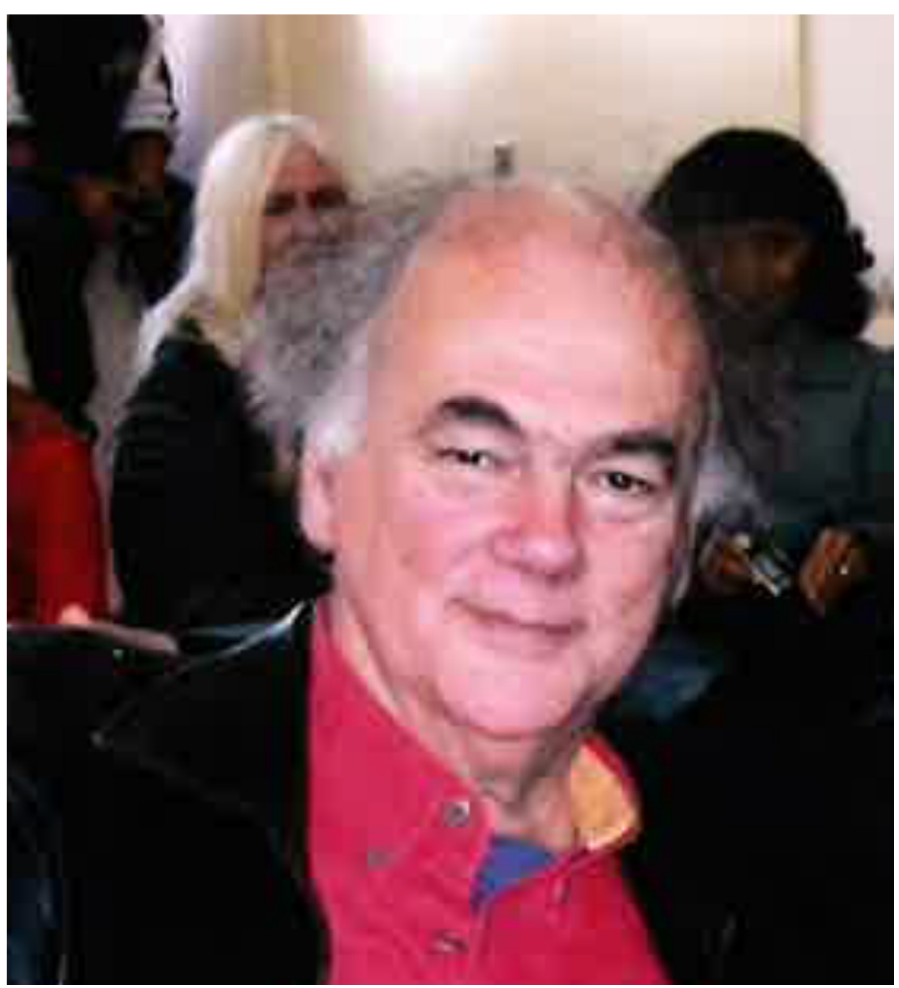

Professor Michael Gaffikin. Photo courtesy of Ciorstan Smark.

\section{DR.Ciorstan Smark, School of Accounting, Economics, and Finance, VOW, Australia.}

When Michael Gaffikin volunteered to step in as my PhD supervisor, I was very scared.

My previous supervisor had needed to step down due to health reasons and I never expected the person to step up into her place would be a foot taller than me, a full professor (as well as Head of School) and resemble a grizzly bear.

What made him even scarier was his mind. He could call up names and references from the depths of memory without Google Scholar and without hesitation. And he did!

This was never going to work because I was too intimidated to speak at any of the Vniversity of Wollongong PhD seminars we drove to from many parts of $\mathcal{N}$ ew South Wales every fortnight.

Then I noticed Gaffikin's kindness. Yes, he was gruff. $\mathcal{N}$, he did not tolerate arrogant fools easily. But if the fool was a young scared student or someone making a genuine attempt to wrestle with an alien concept, he was more than tolerant, he was generous and funny.

$\overline{{ }^{1} \text { University of Wollongong, Australia. }}$ 
Later, as a young (ish) PhD Supervisor myself, Gaffikin was where you went for sage advice when you didn't know where to send a thesis or how to steer a student. He was a comfort and an advisor when a tough examination report had come through. He was, in fact a rock and the Man (Person) that I most wished to emulate in terms of my career and in terms of the positive influence he had on so many lives. But to be Gaffikin, I would need to be at least a foot taller. In so many ways.

\section{Associate Professor Prem Yapa, School of Accounting, RMIT University, Mel6ourne, Austrafia}

I first met Michael in mid1993 when I visited University of Wollongong. He was the Head of the Accounting Department at that time. I was introduced to Michael by Assoc. Prof. Dr. Hema Wijewardena who was an academic attached to the Department of Accounting at Vniversity of Wollongong. I discussed with Michael about my PhD research proposal and a few weeks later I was admitted to the program. I worked in the University of Brunei Darussalam in South East Asia as the Head of Accounting Studies while I was doing my PhD. I invited Michael to my department as a visiting professor in 1995 to advise on our undergraduate and postgraduate curriculum development programs. He was very instrumental in the development of these programs in the University of Brunei Darussalam. I learnt a lot from fim and his advice was well received by the university of Brunei Darussalam authorities. I examined a PhD student of Michael's in 2014 on the influence of Buddhism on accounting in medieval China. It was a great piece of work. My association with Michael, during and after my PhD, profoundly changed my intellectual and academic views on life, society and particularly in accounting. I am for ever deeply indebted to him for providing this to me. I will really miss Michael's presence 6ut I will carry with me the many lessons I learned from him.

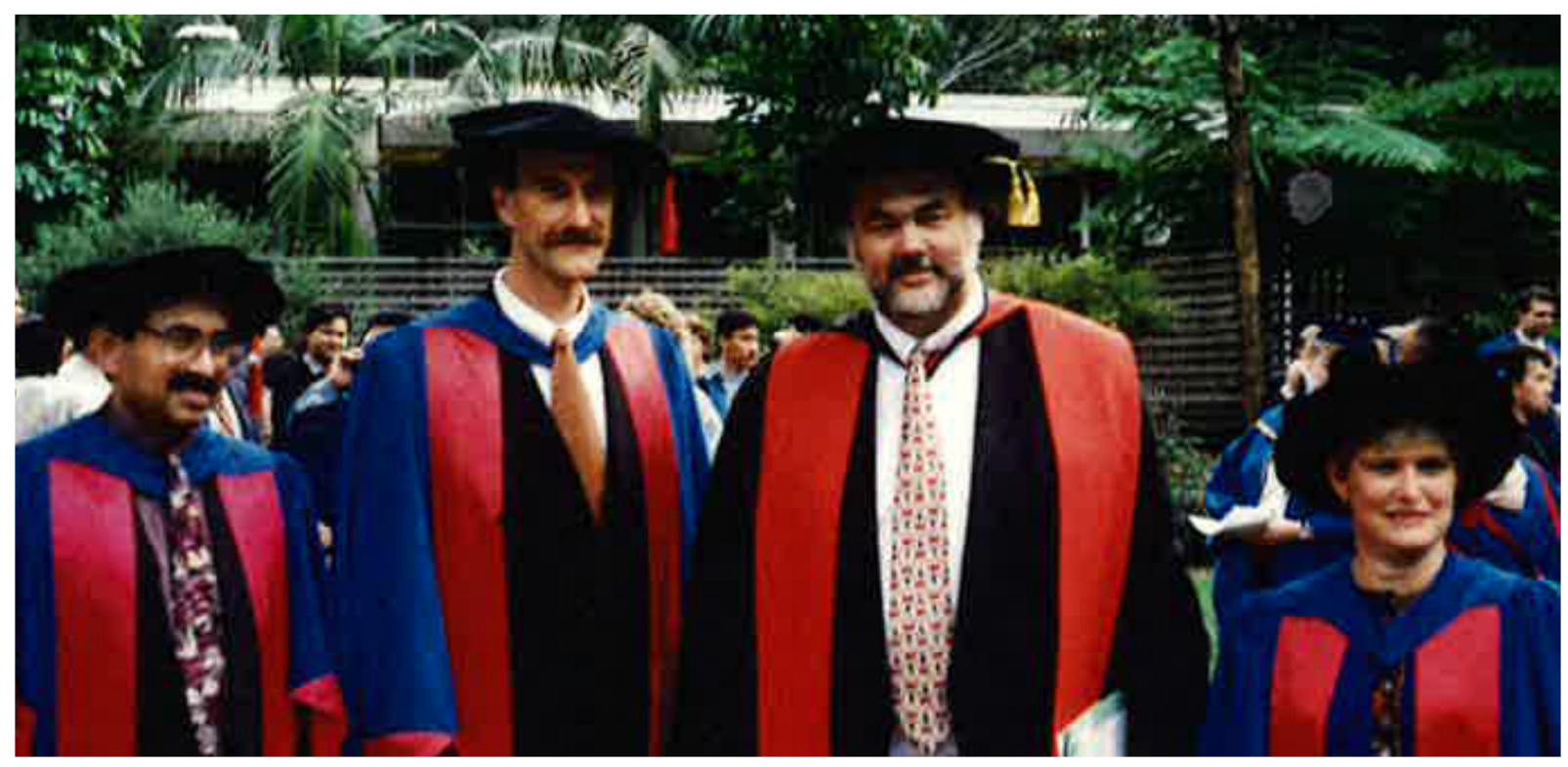

Dr Sudhir Lodh, Professor Warwick Funnell, Professor Michael Gaffikin, Professor Kathie Cooper. Photo courtesy of Dr. Sudhir Lodh. March 1995. 


\section{Professor Monir Z. Mir, School of Information Systems and Accounting Faculty of Business, Government \& Law University of Canberra, Austrafia}

Michael's influence in my career and in my life in Australia is phenomenal. He not only supervised my PhD thesis but also has made me a better person - a better thesis supervisor also. He was my continuous mentor and like a guardian. Whenever I was facing difficulties in my job or personal life, I resorted to his advice. One of my fondest recent memories with him is that I sent him from Canberra a chilli plant seedling a couple of years ago. The chilli is called 'Bhut Jolokia'- one of the world's highest ranked hot chillies. He planted it in his garden. We joked and laughed about it when he spoke to me saying how hard he finds now a days to eat hot chillies as he is getting older. The plant may still be standing in his garden! Rest in peace Michael. We will move forward your legacies, your values.

\section{Professor David Saerang, former Dean of faculty of Economics and Business, Sam Ratulangi University, Manado, Indonesia.}

Professor Michael Gaffikin is the most influential person in my life. He was the one who led and guided me to accomplish my Masters and PhD degrees. He is my best mentor ever and promoted me to reach my highest academic achievement. Your smile when I received my certificate on graduation is still fresh in my mind. You have dedicated much of your life to educate people and I am one of those who were very lucky to be your students. Unfortunately, your visit to Manado in 2003 was our last encounter. My wife and I were very proud to be your hosts and to serve you in my hometown. Now you are gone but your legacy will remain everlasting. The seeds that you sowed through us have been passed to the next generations and this will be a never ending process.

Rest in peace my lovely great mentor. My very deep condolences to Angela for the loss of the great hero, may God give you strength.

\section{DR. Ali Djamhuri, Faculty of Economics and Business, University of Brawijaya, Malang, Indonesia.}

I and my family were so sad to hear that Professor Gaffikin passed away yesterday in Dublin, Ireland. We feel loss of an honourable accounting scientist who was really so helpful and attentive to all his students everywhere. Rest in peace, Professor.

I was his masters student in accounting in 1989-1990. Since my graduation at the end of 1990 I have met him three times, once in Bali and twice in Malang, Indonesia. He visited my house twice, once when I was in Wollongong as his student and the other one when he was for the first time visiting Malang. I always remember him as a professor that had a great personality who dedicated all his academic life to promote science of accounting globally. His writings, either in his capacity as an accounting historian or as a non-positivist accounting scholar, had inspired me personally. I feel so sad hearing that he passed away so suddenly. I have been indebted so much for his kindness.

May he be in peace for ever.

\section{DR. Jira Yammeesri, School of Accountancy, University of the Thai Chamber of Commerce, Bangkok, Thailand.}

Professor Emeritus Michael Gaffikin was an inspiration to many of us. We used one of his prolific accounting text6ooks when I was an undergraduate student at Assumption Vniversity of Thailand. The book, gave a unique perspective in accounting and I immediately found my passion. Three years later, I had a pleasure of meeting Professor Michael in person at Wollongong University in Australia during my graduate programme. He was an open-mind professor who was willing to help indiscriminately, even a foreign student like myself. He genuinely cared about us and encouraged me to pursue the doctoral degree. He continued to guide me 
through the Ph.D. programme with integrity and professionalism. During that time, he taught me so much and shaped me to have become a better professor today. I am forever in his debt. He was a great father figure in the academic world and he will be sorely missed by all.

\section{Dr Corinne Cortese, School of Accounting, Economics \& Finance, VOW, Australia}

I remember vividly the first time I ever encountered Michael Gaffikin. I was a first-year commerce student nervously awaiting my very first university lecture along with 400 other students in a packed lecture theatre. I had not decided on my major, and I had certainly given no thought to it being accounting. Then, in walked the accounting professor to address the class. An Albert Einstein-looking character, Michael epitomised everything I imagined a professor would be as he delivered his two-hour lecture with authority, eloquence, and not a shred of paper for reference. I recall thinking, "Wow, I want to be a part of this." Fast-forward nine years, and I was able to call Michael my academic grandfather, as he'd supervised the PhDs of my own PhD supervisors. I have been lucky enough to have Michael guide my academic career, mentor my interest in history and critical theory, and provide invaluable counsel in times of uncertainty.

Michael and I were both in Turkey for the European Accounting Association conference, held in Istan6ul in 2010. I remember traipsing through the Grand Bazaar and surrounding carpet shops as Michael searched high and low for the right Turkish carpet to send to his daughter. I also remember him vowing to stay away from the leather vendors because he already had "far too many leather jackets". He bought one. When we stopped for lunch, we were talking about the developments of critical theory in the accounting literature and, as usual, I was struggling to keep up with his intellectual might; also as usual, Michael was patiently guiding me along. Then he stopped suddenly and asked me, "Well, what do you think are the differences between post-modernism and post-structuralism?" After almost choking on my red lentil soup (purchased at Michael's insistence that it was wonderful; it wasn't), I fumbled an almost passable answer, and have spent much time since making sure that I have a good answer to that question, and others that I imagined Michael might someday ask me. I have been put on the spot like this by Michael many times. Each time, he has profoundly affected my search for knowledge, in part because I've really wanted to know, and in part because I've really wanted him to be impressed that I know. The last time I saw Michael, we were continuing our conversation about history and critical theory, and I was furiously reading every book that Michael suggested so that I could contribute to our discussions. Such is the magnitude of Michael's influence: "It is the supreme art of the teacher to awaken joy in creative expression and Knowledge" (Albert Einstein).

\section{DR. Basuki, Faculty of Economics and Business, University of Airlangga, Surabaya, Indonesia.}

The news that Michael has passed away shocked me. He was a great man, and a very helpful teacher. My deepest condolences for his leaving to meet his Creator. Rest In Peace my GURV, I and all your students will never ever forget you.

\section{Professor Eko Ganis Sukoharsono, Faculty of Economics and Business, University of Brawijaya, Malang, Indonesia.}

I am made so sad by the news. I have no words to express my condolences for his peace in rest. Emeritus Professor Michael Gaffikin is very good person, helpful and very kind to anyone. We will miss him very much. Praying that God grants his peace for him. Amin. 


\section{Professor Iwan Triyuwono, Faculty of Economics and Business, University of Brawijaya, Malang, Indonesia.}

I am very sad to hear the news. I was one of his PhD students. Professor Michael Gaffikin is a very good, helpful, and nice person. He was a real GURV to me. He was the Guru who enlightened me during my study at the University of Wollongong. May God 6less him with love and rest in a very peace and beautiful paradise.

\section{DR. Lindawati, Faculty of Economics and Business, Binus University, Jakarta, Indonesia.}

My deepest condolences for my beloved farther, someone special for my during my life in Australia as his student that supported, guided, loving with patience to help me to achieve my degree and change my life. Thank you my professor, rest in peace.

\section{Adjunct Professor Helen Irvine, CPA. School of Accountancy, QUT Business School}

I met Professor Michael Gaffikin just as he moved to Wollongong and took up his position as Head of the Department of Accounting. Like him, I had just moved to the area, and had little idea at the time how influential he would be in my life. Michael was a visionary leader and a true intellectual. He created a culture of cooperation and research in the Department that made it a great place to be. I believe he sacrificed his own academic achievements in order to supervise and mentor a vast number of PhD students, of which I was one, at the same time building up the research reputation of the Department. An artist and creative person at heart, Michael experienced frustrations with university bureaucracy, and those of us who worked with him recognised a somewhat morose demeanour at times. Nevertheless, he had an open door policy, and was always available. He was hospitable, hosting numerous dinners at his Mangerton home with his delightful wife Angela. He invited well reputed academics from all over the world, exposing staff and students to a breadth and depth of scholarship that was inspiring. On a personal level, I owe him a debt of gratitude. He believed in me, provided me with fantastic opportunities to extend my scholarship and work experience, gave me tremendous freedom in doing my $P$ hD (even though I wasn't postmodern enough for him!), and was some6ody I relied on for sound advice and wisdom even after I moved away. I will miss him!

\section{DR. Parulian Silaen, School of Accounting, Economics, and Finance, VOW, Australia}

Professor Emeritus Michael Gaffikin is the most influential person in my life in Australia. He guided me to pursue my degree from Masters to PhD. He is a great GURU that is unforgettable in my life. He is like a father to me and to many of my colleagues from Indonesia. He was patiently nurturing me to step into the tunnel of research until I can walk by myself to cross the tunnel and to be in my current academic life. You changed my intellectual and academic views on life, society and specifically on accounting. Thank you professor, thank, you my Guru. The seeds of value that you sowed through us will be handed over to the next generation. You will never be forgotten.

\section{Associate Professor Mary Kaidonis, School of Accounting, Economics \& Finance, VOW, Australia}

In 1988 Michael wrote the "Legacy of the Golden Age: recent developments in the methodology of accounting", in which he argued that

"contemporary researchers have a debt to the 'golden age' of theorists".

However, there are many of us who have a debt to Michael Gaffikin.

Michael was a formidable scholar who challenged the status quo and challenged many of us. He also rattled the bureaucratic cage of accounting and academia and along the way, I dare say, he unsettled a few people. For many years he bore the burgeoning administrative load of head of school and forfeited countless weekends 
reading chapter after chapter of $P h \mathcal{D}$ theses. Michael was also my $\mathcal{P}$ hd supervisor and I am grateful for the freedom I had to find my voice and academic home within critical theory. We also had scope to challenge the status quo in what and how we taught accounting, so that we were passionate about being accounting academics.

During his time at the University of Wollongong (1988 -2006) he forged one of the most successful periods of this school's history. Michael put the school on the national and international map creating a tradition of doctoral consortia which lasted over 20 years. The many international academics who came to VOW came because of the respect they held for Michael and they also became our friends.

Michael, thank you for your vision and your relentless hard work. Thankyou for your legacy of a golden age.

\section{Dr Anura De Zoysa, School of Accounting, Economics \& Finance, VOW, Austrafia}

Professor Michael Gaffikin was a remarkable person in many ways. For me personally he was an incredible educator, an honourable mentor, a visionary Head of School, a friend and a colleague who only comes along once in a lifetime. There are so many things I feel but am unable to put into words, because the impact he had on my life, and on the lives of so many of my colleagues, is one that cannot be fully comprehended. While he was so passionate about critical accounting research and was a champion of promoting it around the world, he truly appreciated and wholeheartedly supported the work of all other accounting researchers. I was lucky enough to be one of those other academics who benefited immensely from his wisdom, wit, support and generosity, which helped me to become a better academic. I remember my first meeting with him in 1999 as a newly enrolled PhD student in the School of Accounting and Finance where he was the Head of School. I went to see him to get his signature for some documents to apply for a VISA to present a paper at an international accounting conference in the $V_{K}$. To my amazement, he not only supported my application 6ut also offered to fully fund my trip to the $V \mathcal{K}$ in appreciation of my research effort. This unexpected support from him gave me a morale boost to work hard on my teaching and research, and enormous confidence to believe in myself that I might have a chance to pursue an academic career in Australia. And I did. Two and a half years later, even before finishing my PhD, Michael hired me as a lecturer in the school in 2001, where I am still serving today. If it was not for Michael, my life would have been very different to what it is today, and I am ever grateful to him for taking a chance on me, a complete outsider, and supporting me throughout my academic career in Australia in every possible way. I know mine is not the only life Michael touched, and this can be seen through the overwhelming response to his unexpected passing. When I look 6ack and think about what was special about him, there were many things that made him a cut above the other leaders that I have had. Despite being a full professor, Head of School, and Associate Dean, he was a very humble and kind person. He treated everyone as equals, and never failed to go out of his way to help them become more successful. Under his leadership, the number of academics with PhDs in the school increased from 2-3 to almost all of the academics, and Michael was the supervisor for the vast majority of those PhDs. In fact, he supervised more than 40 PhD students to completion during his time at VOW, an amazing feat! Michael contributed immensely to the development of accounting education in many countries, especially in Asia where a huge number of his former students are serving in different capacities, such as Vice Chancellors, Deans and Heads of Schools. Even after his retirement, he was always there for me and for all of my colleagues whenever we needed him for advice. Until his sudden passing, he endlessly helped others, believed in others, and supported others, all the while never asking for anything in return. For that we are eternally grateful to him. May God bless Professor Michael Gaffikin! 


\section{Dr Sudhir Lodh, School of Accounting, Economics \& Finance, VOW, Austrafia}

Emeritus Professor Michael Gaffikin was not only my PhD supervisor at the University of Wollongong (UOW); he was a mentor, friend and a senior colleague. I met Michael in September 1988 as one of his first batch of PhD students. I can recall when I called him from Belgium after completion of my MMBA degree from the Catholic University of Leuven (KVL), Michael warmly invited me to join as his student. Accordingly I started my journey to Wollongong and still belong to VOW but how unfortunate that Michael had to leave us so young! Back in the 1990s when all the Critical Accounting Gurus including Professor Tony Lowe, Professor Richard Laughlin, Professor Wai Fong Chua, Professor Norman MacIntosh, Professor Anthony (Tony) Tinker, Professor Jane Broadbent, Professor David Cooper, Professor Bill Birket, Professor Peter Booth, Professor Alistair Preston, Professor Marylyn Neimark, Professor Tom Mouck, Professor Alan Mapper and Professor Prem Sikka (to name a few) used to visit the School of Accounting and Finance (the then) at VOW, it was seen to be a home for critical accounting scholars. It was Michael who made this possible. I still feel proud to be part of it. I had co-authored papers with Michael on several critical studies on accounting. Even over the last couple of years after his retirement we were working together on a paper. Michael was, as always, helpful to people with highest level of integrity and tolerance. He was a kind and extraordinary human being. We still adopt his book - "the accounting theory" - in our undergraduate and postgraduate programs. It is so enrich philosophically and enfightening to profoundly understand our theory and practice of accounting. We all can only pray for this critical accounting Guru's departed soul to be placed in Heaven and remain in all of our hearts.

\section{Dr. Jamal Roudaki, Department of Financial and Business System, Faculty of Agribusiness and Commerce, Lincoln Vniversity, New Zealand.}

I remember Professor Michael Gaffikin in his office as chair of Accounting and Finance early 1990s when I was doing my PhD, as a smiley person who was willing to help everybody who passed beside him. Michael has accepted to attend an accounting seminar in Iran, where I hosted him, he was patient enough to get the visa approved and travelling more than 20 hours flight for his conference presentation. He expressed extreme love and passion while visiting the ancient Iranian Civilization. He was a reliable point of reference for all of his students including me.

On the 22nd of February 2017 the message was short 6ut very sad that he has passed away. As an alumni of VoW it was a shock and unbelievable news.

Michael, we have never forgotten you and your memories, you are in our heart forever. Thank you for everything you gave us while we were working together in VOW. May Michael be granted eternal peace. 


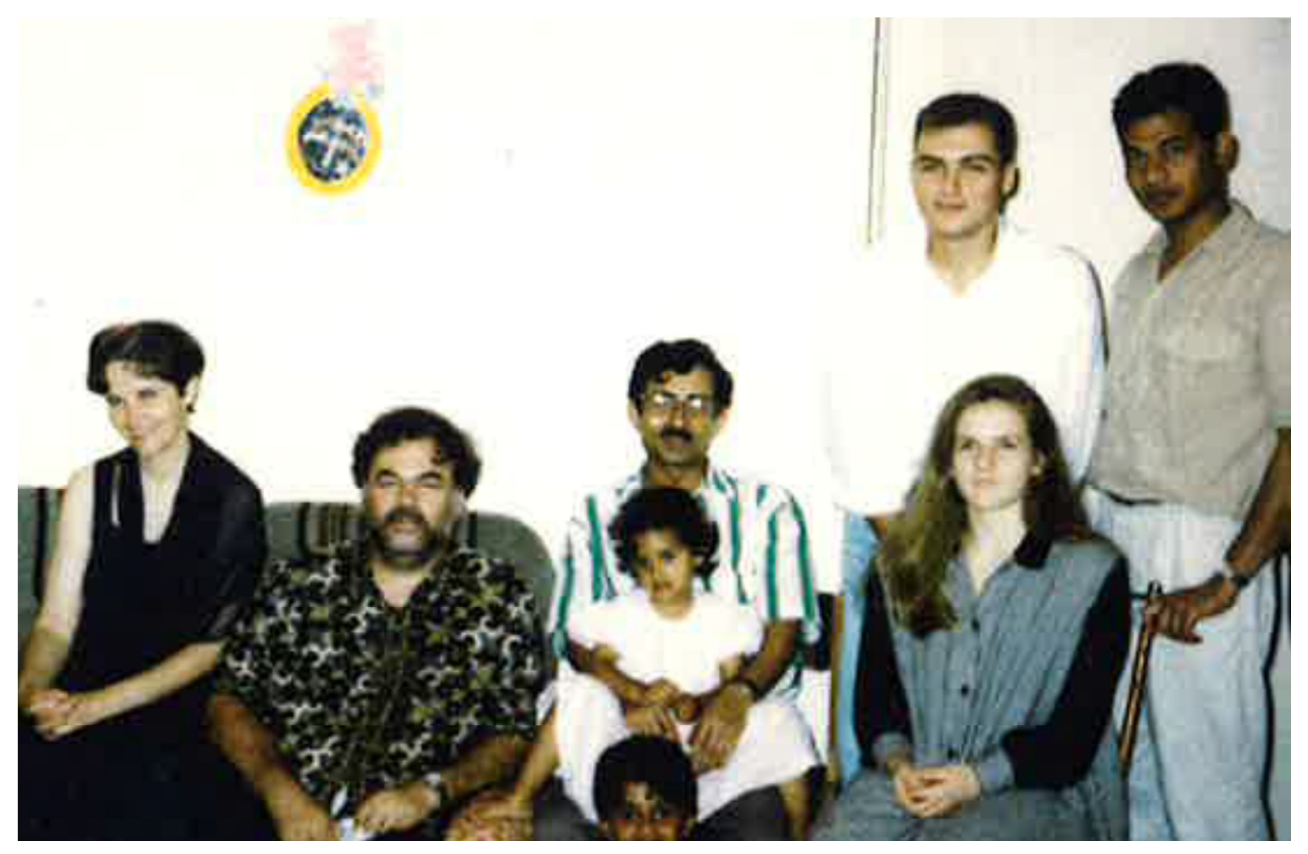

Angela Gaffikin, Professor Michael Gaffikin, Dr. Sudhir Lodh (with two unnamed children), Professor Alex Frino, Betty Frino, Navid Lodh. 1995. Photo courtesy of Dr. Sudhir Lodh. 